\title{
EDITORIAL
}

\section{Playing a dirty trick on airway smooth muscle: house dust mite does it again}

\author{
S. Zuyderduyn and P.S. Hiemstra
}

(1) ncreased airway smooth muscle (ASM) mass is a hallmark of asthma and is thought to be the main contributor to the increased airway hyperresponsiveness seen in asthmatics [1]. This increase is related to disease severity (reviewed in [2]) and caused by hyperplasia alone or in combination with hypertrophy, depending on the generation of airways [3, 4]. Why and how ASM mass is increased is incompletely understood, but in vitro studies have shown that ASM cells isolated from asthmatics proliferate faster in culture [5]. In addition, cultured patient cells produce more chemokines and an altered array of extracellular matrix proteins compared with those of healthy individuals [6, 7]. In vitro studies have shown that upon isolation, ASM cells display contractile function, but they rapidly change phenotype (i.e. acquire proliferative and synthetic capacity) and become noncontractile during culture under serum-rich conditions [8]. When these synthetic-proliferative cells are serum-deprived for a prolonged period of time, a small population (so-called "hypercontractile" cells) starts re-expressing contractile protein genes, such as ACTA2 (encoding $\alpha$-smooth muscle actin ( $\alpha$-SMA)) [9]. This dedifferentiation/modulation and differentiation/maturation of ASM cells is referred to as phenotype switching or phenotypic plasticity, and although this phenomenon clearly exists in vitro, we do not know whether this plays a role in thickening of the ASM layer.

The increase in ASM proliferation in asthma is thought to be associated with decreased levels of CCAAT enhancer protein (c/EBP) $\alpha$ (encoded by the CEBPA gene), a crucial controller of cell cycle progression, differentiation and inflammation. The biological effects of this protein are exerted by the full-length (p42) isoform and counteracted by a shorter isoform (p30), which is formed after translation of the protein. Previously, it was shown that ASM from asthmatics has reduced expression of $c / E B P \alpha$, leading to reduced effects of glucocorticoids on proliferation of ASM cells [10]. Subsequently, it was shown that both the $\mathrm{p} 42$ and $\mathrm{p} 30$ isoforms of $\mathrm{c} / \mathrm{EBP} \alpha$ are reduced in asthmatic ASM cells and that culture in medium containing 5\% fetal calf serum reduced the expression even more. Reduced expression was found to be the result of impaired translation and it was associated with decreased expression of the translation regulator eIF4E (eukaryotic initiation factor 4E) [11]. In addition to increased proliferation, interleukin (IL)-6

Dept of Pulmonology, Leiden University Medical Center, Leiden, The Netherlands.

CORRESPONDENCE: S. Zuyderduyn, Dept of Pulmonology, Leiden University Medical Center; C3-P, P0 box 9600, 2300 RC, Leiden, The Netherlands. E-mail: s.zuyderduyn@lumc.nl release (induced by growth factors) is increased in ASM from asthmatics and lack of $\mathrm{c} / \mathrm{EBP} \alpha$ is thought to be important for this process. Whether the change in ASM in asthmatics is innate or acquired due to exposure to external stimuli is yet to be discovered.

Bronchial provocation using house dust mite (HDM) allergens results in bronchoconstriction in allergic patients. In addition to immunological mechanisms involving immunoglobulin (Ig)E and T-helper type 2 cells, it was shown that HDM also exerts direct effects on various cell types, including proteasedependent cell detachment in epithelial cells [12] and IgEindependent activation of mast cells [13]. In a mouse model of allergic airway inflammation, it was recently shown that Tolllike receptor 4 expression on epithelial cells was sufficient and necessary for dendritic cell activation and induction of airway inflammation by HDM, suggesting an important role for structural cells in the induction of inflammation in asthma [14]. As HDM disrupts the epithelial barrier, it is plausible that HDM will also reach and affect other cell types underneath the epithelium. Exposure of rabbit ASM strips to the purified Der $\mathrm{p} 1$ allergen increased airway hyperresponsiveness to acetylcholine and reduced relaxation responses to isoproterenol, and this effect was attributed to the protease activity of Der p 1 [15]. Passive sensitisation of human bronchial rings using IgE-rich serum from HDM-allergic patients increases bronchoconstriction to histamine and other stimuli, suggesting that the immunological compartment is perhaps not necessary [16]. These data suggest that the effects of HDM can be IgE-dependent and -independent, as well as protease-dependent and -independent.

In this issue of the European Respiratory Journal (ERJ), MigLINO et al. [17] show that HDM extracts also affect ASM function through protease-dependent and -independent mechanisms. These investigators show that stimulation of ASM cells obtained from mild-to-moderate asthmatics with HDM results in increased cell proliferation and production of IL-6, whereas ASM obtained from healthy controls did not respond to HDM. $A$ reduction of $\mathrm{c} / \mathrm{EBP} \alpha$ expression in response to $\mathrm{HDM}$ was shown specifically in asthmatic ASM cells, and was found to be mediated by two mechanisms: by a protease-independent mechanism involving increased expression of calreticulin (CRT) and by protease-activated receptor (PAR)2.

MigLino et al. [17] show an inverse relationship between $\mathrm{c} / \mathrm{EBP} \alpha$ and CRT: when CRT was inhibited using small interfering RNA, c/EBP $\alpha$ levels were restored. CRT may mediate some of the effects of HDM by binding to a GC-rich sequence in the CEBPA mRNA, resulting in inhibition of translation. 
Other functions of CRT include calcium homeostasis and quality control of protein folding. In a mouse model, it was shown that increased contractility in lung slices correlated with increased calcium in the sarcoplasmic reticulum (SR) [18]. CRT in the SR serves as a calcium chelator and may prevent release of calcium from the SR into the cytoplasm and, therefore, contraction. However, as other proteins involved in calcium release are also increased in these mouse models, the role of increased CRT in this process may be limited [19]. In addition to calcium handling, CRT also has a chaperone function, as it prevents export of misfolded proteins to the Golgi apparatus by binding to these proteins [20, 21]. Therefore, increased expression of CRT in asthmatic ASM cells may not only inhibit $\mathrm{c} / \mathrm{EBP} \alpha$ expression but also serve to prevent cells from going into endoplasmatic reticulum (ER) stress. This may be important to control ASM function, as shown in studies in which induction of ER stress in mouse ASM cells resulted in altered ECM production, which may lead to increased adhesion of inflammatory cells [22].

These findings of MigLINO et al. [17] in this issue of the ERJ are very interesting, as they suggest that the reduction of $c / E B P \alpha$ expression seen in asthmatic ASM can be the result of exposure to HDM, and that this effect is independent of the immunological compartment. However, as all asthmatic patients were atopic, we can not formally exclude the possibility that their ASM cells had already been primed in vivo by HDM-specific $\operatorname{IgE}$, although it appears unlikely that the presence of $\operatorname{IgE}$ persisted in culture. Recent studies have shown that the highaffinity IgE receptor (FcERI) is present on ASM cells [23] and that sensitisation of ASM cells with $\operatorname{IgE}$ results in increased transcription of various CC- and CXC-chemokines [24]. Further studies are needed to investigate whether immunological mechanisms in vivo have contributed to the property of the cells in culture, or whether the same phenomenon is also observed in cells from asthmatic donors that do not respond to HDM or in nonatopic asthmatics. In any case, the fact that such a disease-specific cellular response persists in culture indicates the importance of, for example, epigenetic mechanisms to explain persistence of the phenotype in small groups of patients such as those studied by MigLiNo et al. [17] (in which genetic studies will not likely reveal differences).

Involvement of PAR2 in HDM-induced effects on ASM cells suggests that other environmental proteases (e.g. in mould, aeroallergens and mites) and endogenous (cell-derived) PAR2 agonists may also alter $\mathrm{c} / \mathrm{EBP} \alpha$ expression. PAR2 activation by trypsin and tryptase is known to induce ASM proliferation and contraction $[25,26]$, and the results of the present study indicate that in ASM from asthmatics, this is mediated by a reduction in $\mathrm{c} / \mathrm{EBP} \alpha$. As mast cell inflammation inside the ASM bundles is found in asthmatics [27] and these cells are sources of these proteases, these cells may affect the $\mathrm{c} / \mathrm{EBP} \alpha$ expression in ASM from asthmatics.

Perhaps differentiation of ASM is also affected, as the authors show that $24 \mathrm{~h}$ stimulation with HDM results in partial inhibition of $\alpha$-SMA expression in asthmatic ASM. This protein is important for the contractile function of ASM cells, and is often used as a contractile marker for ASM cells. Phenotype switching of ASM cells from contractile to synthetic-proliferative cells may underlie the increase in ASM bundles in asthmatics. Another protein involved in contraction, myosin light chain kinase (MLCK), has $\mathrm{c} / \mathrm{EBP}$ binding sites in its promoter, suggesting that reduced $\mathrm{c} / \mathrm{EBP} \alpha$ expression could lead to reduced expression of MLCK and, therefore, reduced contractility. The current study by MigLINO et al. [17], together with other studies, suggests that $\mathrm{c} / \mathrm{EBP} \alpha$ is involved in various ASM functions, including induction of inflammation, proliferation, contractility and differentiation.

In view of the role of $\mathrm{c} / \mathrm{EBP} \alpha$ in various ASM functions, it is tempting to speculate that $\mathrm{c} / \mathrm{EBP} \alpha$ could be used as a target for treatment of asthma. Introducing this protein into ASM cells from asthmatics in culture was shown to reduce proliferation rates [10]. A recent study has shown that ASM proliferation is an ongoing process in moderate-to-severe asthmatics [28], suggesting that introduction of $\mathrm{c} / \mathrm{EBP} \alpha$ may be beneficial in preventing further increases in ASM mass. The effects of HDM on ASM proliferation suggest that reducing the exposure to HDM could have positive effects; however, in vivo studies in mice exposed to HDM, and studies showing correlations between atopic status and $\mathrm{c} / \mathrm{EBP} \alpha$ expression are needed to further substantiate the role of HDM-induced changes in ASM cells in asthma.

The findings of MigLiNo et al. [17] further highlight the active role of ASM cells in airway remodelling and inflammation, and suggest that environmental factors may contribute to changes in these cells in asthmatics that persist even into the cell culture laboratory.

\section{STATEMENT OF INTEREST}

Statements of interest for both authors can be found at www.erj. ersjournals.com/site/misc/statements.xhtml

\section{REFERENCES}

1 Lambert RK, Wiggs BR, Kuwano K, et al. Functional significance of increased airway smooth muscle in asthma and COPD. J Appl Physiol 1993; 74: 2771-2781.

2 Zuyderduyn S, Sukkar MB, Fust A, et al. Treating asthma means treating airway smooth muscle cells. Eur Respir J 2008; 32: 265-274.

3 Woodruff PG, Dolganov GM, Ferrando RE, et al. Hyperplasia of smooth muscle in mild to moderate asthma without changes in cell size or gene expression. Am J Respir Crit Care Med 2004; 169: 1001-1006.

4 Ebina M, Takahashi T, Chiba T, et al. Cellular hypertrophy and hyperplasia of airway smooth muscles underlying bronchial asthma. A 3-D morphometric study. Am Rev Respir Dis 1993; 148: $720-726$.

5 Johnson PR, Roth M, Tamm M, et al. Airway smooth muscle cell proliferation is increased in asthma. Am J Respir Crit Care Med 2001; 164: 474-477.

6 Chan V, Burgess JK, Ratoff JC, et al. Extracellular matrix regulates enhanced eotaxin expression in asthmatic airway smooth muscle cells. Am J Respir Crit Care Med 2006; 174: 379-385.

7 Johnson PR, Burgess JK, Underwood PA, et al. Extracellular matrix proteins modulate asthmatic airway smooth muscle cell proliferation via an autocrine mechanism. J Allergy Clin Immunol 2004; 113: 690-696.

8 Halayko AJ, Salari H, Ma X, et al. Markers of airway smooth muscle cell phenotype. Am J Physiol 1996; 270: L1040-L1051.

9 Halayko AJ, Camoretti-Mercado B, Forsythe SM, et al. Divergent differentiation paths in airway smooth muscle culture: induction of functionally contractile myocytes. Am J Physiol 1999; 276: L197-L206. 
10 Roth $\mathrm{M}$, Johnson PR, Borger $\mathrm{P}$, et al. Dysfunctional interaction of $\mathrm{C} / \mathrm{EBP} \alpha$ and the glucocorticoid receptor in asthmatic bronchial smooth-muscle cells. N Engl J Med 2004; 351: 560-574.

11 Borger $\mathrm{P}$, Miglino N, Baraket $\mathrm{M}$, et al. Impaired translation of CCAAT/enhancer binding protein alpha mRNA in bronchial smooth muscle cells of asthmatic patients. J Allergy Clin Immunol 2009; 123: 639-645.

12 Herbert CA, King CM, Ring PC, et al. Augmentation of permeability in the bronchial epithelium by the house dust mite allergen Der p1. Am J Respir Cell Mol Biol 1995; 12: 369-378.

13 Machado DC, Horton D, Harrop R, et al. Potential allergens stimulate the release of mediators of the allergic response from cells of mast cell lineage in the absence of sensitization with antigen-specific IgE. Eur J Immunol 1996; 26: 2972-2980.

14 Hammad H, Chieppa M, Perros F, et al. House dust mite allergen induces asthma via Toll-like receptor 4 triggering of airway structural cells. Nat Med 2009; 15: 410-416.

15 Grunstein MM, Veler H, Shan X, et al. Proasthmatic effects and mechanisms of action of the dust mite allergen, Der $p 1$, in airway smooth muscle. J Allergy Clin Immunol 2005; 116: 94-101.

16 Schmidt D, Ruehlmann E, Branscheid D, et al. Passive sensitization of human airways increases responsiveness to leukotriene C4. Eur Respir J 1999; 14: 315-319.

17 Miglino N, Roth M, Tamm M, et al. House dust mite extract downregulates $\mathrm{C} / \mathrm{EBP} \alpha$ in asthmatic bronchial smooth muscle cells. Eur Respir J 2011; 38: 50-58.

18 Bergner A, Kellner J, Silva $\mathrm{AK}$, et al. $\mathrm{Ca}^{2+}$-signaling in airway smooth muscle cells is altered in T-bet knock-out mice. Respir Res 2006; 7: 33.

19 Kellner J, Tantzscher J, Oelmez H, et al. Mechanisms altering airway smooth muscle cell $\mathrm{Ca}^{2+}$ homeostasis in two asthma models. Respiration 2008; 76: 205-215.
20 Liu H, Bowes RC III, van de Water B, et al. Endoplasmic reticulum chaperones GRP78 and calreticulin prevent oxidative stress, $\mathrm{Ca}^{2+}$ disturbances, and cell death in renal epithelial cells. J Biol Chem 1997; 272: 21751-21759.

21 Zhang JX, Braakman I, Matlack KE, et al. Quality control in the secretory pathway: the role of calreticulin, calnexin and $\mathrm{BiP}$ in the retention of glycoproteins with C-terminal truncations. Mol Biol Cell 1997; 8: 1943-1954.

22 Lauer ME, Mukhopadhyay D, Fulop C, et al. Primary murine airway smooth muscle cells exposed to poly $(\mathrm{I}, \mathrm{C})$ or tunicamycin synthesize a leukocyte-adhesive hyaluronan matrix. J Biol Chem 2009; 284: 5299-5312.

23 Gounni AS, Wellemans V, Yang J, et al. Human airway smooth muscle cells express the high affinity receptor for IgE (Fc epsilon RI): a critical role of Fc epsilon RI in human airway smooth muscle cell function. J Immunol 2005; 175: 2613-2621.

24 Redhu NS, Saleh A, Shan L, et al. Proinflammatory and Th2 cytokines regulate the high affinity IgE receptor (FceRI) and IgEdependant activation of human airway smooth muscle cells. PLoS One 2009; 4: e6153.

25 Chambers LS, Black JL, Poronnik P, et al. Functional effects of protease-activated receptor-2 stimulation on human airway smooth muscle. Am J Physiol Lung Cell Mol Physiol 2001; 281: L1369-L1378.

26 Berger P, Perng DW, Thabrew H, et al. Tryptase and agonists of PAR-2 induce the proliferation of human airway smooth muscle cells. J Appl Physiol 2001; 91: 1372-1379.

27 Brightling CE, Bradding P, Symon FA, et al. Mast-cell infiltration of airway smooth muscle in asthma. N Engl J Med 2002; 346: 1699-1705.

28 Hassan M, Jo T, Risse PA, et al. Airway smooth muscle remodeling is a dynamic process in severe long-standing asthma. J Allergy Clin Immunol 2010; 125: 1037-1045. 